\title{
Características generales del poblamiento y la arqueología funeraria visigoda de Hispania
}

\author{
Gisela Ripoll López *
}

Todos los problemas que presenta el conocimiento de un asentamiento urbano están en conexión con la economía. Esta economía o vida económica puede relacionarse con varios tipos de hábitat, dependiendo del terreno y la clase de explotación que se lleve a cabo. Asi, pueden existir hábitats absolutamente urbanos, es decir, ciudades donde existe una vida administrativa y una organización eclesiástica de relativa importancia. Los otros tipos de hábitat responden a un modelo económico rural. Se trata de hábitats de altura, hábitats de llanura y hábitats dispersos. Todos ellos pueden configurarse de forma temporal, permanente 0 continuada durante mucho tiempo. Puesto que la toponimia es poco útil para el estudio del poblamiento en la Peninsula lbérica, estamos obligados a encontrar otro tipo de soluciones para definir los asentamientos '.

- Departamento de Prehistoria e Historia Antigua. UNED.

Un primer acercamiento al tema preciso que exponemos aqui lo realizamos en los dos primeros capitulos de nuestra tesis doctoral, Gisela RIPOLL LOPEZ, La ocupación visigoda a través de sus necropolis (Hispania). Edicions en Microfitxa de l'Universitat de Barcelona, Barcelona 1986 (1989), en prensa. R. MENÉndez PIDAL. Toponimia prerrománica hispana, Madrid 1968. Para la toponimia en Aquitania, vease el libro de M. ROUCHE, L'Aquitaine des wisigoths aux arabes. La naissance d'une region (418-781). Paris 1979. Sobre el mismo tema se pueden consultar: A. M. ${ }^{a}$ JIMEnez GarnicA, El reino visigodo de Tolosa. Origen y desarrollo, Valladolid 1983. Sobre los hábitats de altura, urbanos o puntos que a veces se pueden considerar defensivos, vease: Lauro OLMO ENCISO, "Problemática de las fortificaciones altomedievales (siglos VI-VIII) a raiz de los últimos hallazgos arqueológicos", Actas del I Congreso de Arqueologia Medieval Española. Huesca, 1985, Zaragoza 1986, vol, il págs. 13-23. 
Parece que la solución tiene que referirse a dos puntos básicos: el hábitat propiamente dicho y las necrópolis. Un ejemplo de estudio de hábitat puede ser el que llevó a cabo P. A. Février en el sur de la Gallia, pero éste es difícilmente aplicable a la problemática hispana ${ }^{2}$, por una serie de cuestiones que se irán viendo más adelante.

El desconocimiento que poseemos del hábitat peninsular en época visigoda, a excepción - aunque también deficiente- de las grandes ciudades y de los centros episcopales, nos lleva a tratar los cementerios de esta época desde un punto de vista no sólo arqueológico sino también teórico. En lo que concierne al aspecto "teórico" entendemos que un cementerio representa una comunidad organizada como grupo jerárquico cuyos lazos de unión son los medios de producción. Por tanto los cementerios o necrópolis puede ofrecernos la información relativa a un hábitat cuya coherencia o interrelación desconocemos. Es lógico pensar que todo asentamiento genera un "hábitat funerario", pero también puede darse el caso de que un antiguo cementerio pueda ser el generador de un hábitat ${ }^{3}$.

Edouard Salin, en su gran obra sobre la civilización merovingia, llevó a cabo un estudio a partir de las necrópolis y en particular de los objetos procedentes de las sepulturas ${ }^{4}$. Para E. Salin, las tumbas reflejan de manera considerable la naturaleza misma del poblamiento, a través de los objetos de ajuar y de los ritos funerarios ${ }^{5}$. Pero debemos actuar con cautela, pues no toda sepultura define una realidad étnico-religiosa, y este es un terreno muy resbaladizo, cuando se pasa de la pura interpretación arqueológica a la hipótesis histórica.

A través de las sepulturas, Edouard Salin, consideró que se podian conocer las diferentes influencias recibidas por la población y en particu-

P. A. FeVrier, "Problemes de l'habitat du Midi méditerranéen à la fin de l'Antiquité et dans le Haut Moyen Áge", Les relations entre l'empire romain tardif, l'empire franc et ses voisins, bajo la dirección de $\mathrm{K}$. Böhner, IXeme Congrés de I'Union Internationale de Sciences Préhistoriques et Protohistoriques, Niza 1976, págs. 145-182.

${ }^{3}$ El caso de Mazan en Vaucluse (Francia) mencionado en el articuio de FEVRier, "Problemes de l'habitat...", obra citada, pág. 164.

${ }^{4}$ Edouard Salin, La civilisation mérovingienne, dapres les sepultures, les textes et le laboratoire, 1 ère partie: les idees et les taits. Paris 1952, págs. 209 y ss.

${ }^{5}$ SaliN, La civilisation mérovingienne.... obra citada, pág. 211. Acerca de ritos funerarios puede consultarse el articulo de B. YOUNG, "Paganisme, christianisation et rites funeraires merovingiens", Archéologie Medievale, VII, 1977, págs. 5-81, 10 figs. Id., "Exemple aristocratique el mode funeraire dans la Gaule merovingienne", Annales Economies, Sociétes, Civilisations, 2, 1986, pág. 302. 
lar la "fusión progresiva entre invasores e invadidos" ${ }^{6}$. En palabras más actuales, Salin, quería decir que en una inhumación se podía llegar a distinguir hasta que punto se hacia patente el proceso de aculturación de los individuos sepultados. De este modo, para el caso hispánico, vemos como la fusión más o menos definitiva entre visigodos e hispanorromanos, quedó establecida a partir del III Concilio de Toledo del año 589, y ésta queda atestiguada arqueológicamente en las sepulturas. El pueblo visigodo abandona progresivamente su vestimenta propia y al mismo tiempo adopta una nueva indumentaria $y$, con ello, unos nuevos elementos de adorno personal ${ }^{7}$.

En Hispania, estos cementerios entran dentro de los clasificados como cementerios alineados o «Reihengräberfelder», característicos en muchos lugares de la actual Europa, básicamente donde existe una presencia poblacional de la época de las migraciones. Durante los siglos VI y VII, florecieron en la Meseta Castellana varios de estos cementerios. Se trata de una concepción única de la necrópolis y por ello la alineación y la orientación son básicas para que ésta se desarrolle e incremente de forma ordenada con el paso de las generaciones. Las enraizadas tradiciones familiares y de clanes y grupos, junto con unas creencias religiosas muy vivas, hicieron que el pueblo visigodo trajese consigo unas costumbres que quedan patentes en la arqueologia funeraria. Recordemos también que los visigodos perdieron rápidamente su lengua original. La onomástica es exigua y no permite reconstruir grupos familiares y supra-familiares. Por todo ello, la pervivencia de tradición en los cementerios es un dato importante frente a la tendencia -en algunos casos determinados- que exagera la romanización sufrida.

Contemporáneamente a estas necrópolis de tradición "germánica" o de la "Reihengräberzivilisation», existen en Hispania, los cementerios de tradición romano-cristiana. La corriente unificadora aparecida hacia el año 589, fecha que mencionábamos más arriba, liberó legal y teóricamente a visigodos e hispanorromanos de unas tradiciones excesivamente pesadas y diferenciales, permitiendo una nueva concepción funeraria, que entra

- SalıN, La civilisation mérovingienne ..., obra citada, pág. 212.

Este tema ha sido tratado por diversos investigadores, como Julio Marínez SantaOlalla, José Ferrandis y Pedro de Palol. Véase de este último: "Fibulas y broches de cinturón de la época visigoda en Cataluña", Archivo Español de Arqueologia, XXIII, 1950, págs. 73-98. Puede consultarse también Gisela RIPOLL LOPEZ, “Reflexiones sobre arqueologia funeraria, artesanos y producción artistica de la Hispania visigoda" $X X X I V$ Corso di Cultura sull'arte Ravennate e Bizantina, Seminario Internazionale di Studi su "Archeologia e Arte nella Spagna tardoromana, visigotica e mozarabica", Rávena, 1987, págs. 343-373, 17 figs. 
ya dentro de la época hispano-visigoda o de unidad confesional, y que se perpetuó además en el periodo alto-medieval.

\section{Historia de un problema sin solución}

Todos los estudios de poblamiento llevados a cabo en la Península Ibérica, se han basado en el número de godos que rompió la linea del limes danubiano y asesinó al emperador Valente en el año 378. Esta mítica fecha marca la conocida "victoria de Adrianópolis". Pero ya el número de individuos cifrados en ese momento varía. ¿Eran 80.000 o 200.000 individuos? Las fuentes son imprecisas en todo momento. Las discusiones acerca del número de godos que poblaron Aquitania y Septimania y que más tarde atravesaron los Pirineos entre los siglos $\vee$ y vI, son largas y se remontan a muchos años. Entre otros, se preocuparon principalmente de este problema Sánchez Albornoz, Abadal, Garcia Gallo y Reinhart. Parece que el problema fue abandonado por la dificultad en encontrar una solución y las discusiones se estancaron.

En el momento en que los visigodos consiguen el tratado de instalación en la Gallia en el año 418, su número oscila entre unas 50.000 y 100.000 personas. Esto representaría una cifra aproximada de 70.000 a 90.000 individuos visigodos en el territorio peninsular hispánico durante el siglo VI, teniendo en cuenta que un cierto número de familias se quedaría en el territorio aquitano y sin tomar en consideración aquellos que siguieron habitando en la Narbonense.

Claudio Sánchez Albornoz no cree factible que en Adrianópolis luchasen tan sólo 80.000 hombres y que esta cifra siguiese constante, en la época de la batalla de Vouillé en el año 507, e incluso hasta la batalla en el rio Guadalete en el año $711^{\circ}$. También a nosotros nos cuesta imaginar una constancia en este número, si además tenemos presente que en Adrianópolis se supone se cuentan los soldados y no todo el conjunto de la población civil y militar. El mismo historiador, considera más verosímil un número aproximado de 200.000 visigodos frente a unos ocho o nueve millones de hispanorromanos. Por el contrario Garcia Gallo, eleva mucho

"C. Sanchez Albornoz, "Tradición y derecho visigodo en León y Castilla", Homenaje a R. Menéndez Pidal, Cuadernos de Historia de España. Buenos Aires 1959, págs. 244265. Véase en particular la pág. 249. 
más el número de hispanorromanos y los calcula en unos doce millones ${ }^{9}$. Según Abadal la oligarquia aristocrático-militar en el reino visigodo hispánico estaria en manos de unas 1.500 familias, es decir unas 7.000 a 10.000 personas. Para dicho investigador el ejército representaria un diez por ciento del total de la población "germánica" peninsular ${ }^{10}$; por tanto se deberia contar con una población global de alrededor 100.000 almas. El investigador alemán W. Reinhart, apoyándose en la base de que en tiempos de Walia existía un número aproximado de visigodos de 80.000 a 100.000 , consideró este número válido para los primeros asentamientos en la Península ". Acertadamente Reinhart opina que los asentamientos visigodos en la Península Ibérica se fueron realizando poco a poco y por pequeños grupos a todo lo largo del siglo $\vee$ y principios del siglo VI.

Abordando el problema años más tarde E. A. Thompson, en su obra general ${ }^{12}$, consideró que la población hispanorromana se situaba en una proporción de diez a uno frente a la población visigoda. Por tanto, seguimos en la cifra que podemos considerar clásica o tópica de 100.000 visigodos y diez millones de hispanorromanos, hecho que no hace avanzar de forma seria el estudio estadístico del poblamiento peninsular.

Más tarde, José Orlandis, creyó que el número de personas componentes de la sociedad visigoda debió ser más alto de 200.000 , y que éste se vio incluso incrementado con la estabilidad del reino de Toledo ${ }^{13}$.

Las cifras que hemos ido citando hasta el momento, oscilantes entre los siglos iv y VII, vemos que han variado muy poco. En resumen se puede considerar que el pueblo visigodo - sin diferenciar la población

3. Garcia Gallo, "El carácter germánico de la épica y del derecho en la Edad Media Española", Anuario de Historia del Derecho Español, XXV, 1955, págs. 583-679.

"R. D'ABADAL, "A propos du legs visigothique en Espagne", Caratteri del secolo VII in Occidente, Spoleto 1959, págs. 545-559. Del mismo autor: Dels visigots als catalans. Barcelona 1974.

"W. Reinhart, "Sobre el asentamiento de los visigodos en la Península", Archivo Español de Arqueologia, XVII!, 1945, págs. 124-139, 10 figs. Dicho autor fue el primero en darse cuenta que, en el intento de realizar una estadística de población, la única posibilidad residia en el estudio minucioso de las necrópolis y sus ajuares, ya que las fuentes escritas no proporcionan datos concretos. P. de Palol siguio en esta linea y elaboró una cartografia muy útil: P. de PALOL, "Demografia y arqueología hispánicas. Siglos IV-VIII. Ensayo de cartografia", Boletin del Seminario de Estudios de Arte y Arqueologia (Valladolid), 32, 1966. págs. 5-67.

12 E. A. Thompson, The Goths in Spain, Oxford, 1969 (traducción castellana, que nosotros seguimos, en Alianza Editorial, Los godos en España, Madrid 1971), pág. 15. 30 y 31.

13 J. Onlandis, Historia social y económica de la Espania visigoda, Madrid 1975, págs 
civil de la militar - representó de un uno a un dos por ciento sobre la totalidad de la población de Hispania. Seguramente nos encontramos ante un problema sin solución, ni tan siquiera llevando a cabo un minucioso estudio de las necrópolis, aunque estimamos que sí nos podemos acercar más a su propia realidad.

\section{Datos estadisticos fiables}

A la particular situación de la Península Ibérica, hay que sumar el desconocimiento arqueológico que poseemos de las estaciones visigodas de la Gallia meridional, es decir la Aquitania y la Septimania. El conocimiento arqueológico de dichas regiones no permite, por el momento, establecer ningún dato fiable de poblamiento a nivel estadistico. El paso de los visigodos por estas regiones citadas es prácticamente inexistente desde un punto de vista arqueológico, y contrasta con los abundantes hallazgos hispánicos. En la Península, el estudio de los cementerios de época visigoda quizá permita elaborar una primera hipótesis de trabajo, acerca del número aproximado de individuos componentes de la sociedad visigoda. Queremos recalcar que estamos hablando de una hipótesis de trabajo y rogamos al lector que lea los siguientes parágrafos recordándolo.

Teniendo en cuenta las diferentes reutilizaciones de las sepulturas de un mismo cementerio y los problemas de herencia generacional, podemos considerar que una necrópolis de 250 sepulturas corresponde a un núcleo de hábitat o vicus de unos 1.500 individuos. Existen en la Península unas veinte necrópolis de este tipo, de cuyo cálculo aproximado resultan un total de 30.000 personas. Existen cerca de unas quince necrópolis de menor envergadura en cuanto al número de sepulturas, cuya media oscila alrededor de las 125 inhumaciones, y cuyo resultado es aproximadamente de 11.250 individuos. A este total hay que sumar las pequeñas necrópolis - en número no mayor a diez - con cincuenta sepulturas cada una, que forman un conjunto de 3.750 personas. Al total de cuarenta y cinco necrópolis conocidas en la Península hay que añadir los ciento cincuenta hallazgos sueltos que desconocemos si pertenecen a grandes comunidades o tan sólo a pequeñas aglomeraciones. Por prudencia creemos que podemos considerar estos hallazgos pertenecientes a un número no mayor de 5.500 individuos. La suma total de personas que ofrecen los cálculos de las necrópolis y de los hallazgos casuales es 
de unos 50.000 individuos, es decir unas 7.500 familias, si partimos de la base de que cada familia se componía de seis miembros.

A estos 50.0000 individuos que nos indican los cementerios peninsulares, tendríamos que sumar los resultados obtenidos para las capitales de provincia, las comunidades urbanas y comunidades rurales dependientes de las iglesias que conocemos, pues estas nunca coinciden, es decir, no existe correspondencia de hábitat con cementerio. Existen cerca de cincuenta iglesias rurales de época visigoda que deberían congregar a pequeñas comunidades de unas cien personas, lo cual sumaria un total de 5.000 individuos. Como mínimo en cada capital de provincia deberian habitar unas 5.000 personas pertenecientes al grupo visigodo, para desempeñar cargos públicos, administrativos, eclesiásticos, etcétera, y representarían por tanto un total de 25.000 personas. Al mismo tiempo calculamos que la sociedad visigoda además de instalarse en aglomeraciones rurales debió asentarse en comunidades urbanas, de menor importancia, y si consideramos que éstas pudieron llegar a sumar un total de cincuenta con unos 1.000 individuos cada una, obtenemos un resultado de 50.000 personas.

El resultado de este cálculo aproximado, tanto de comunidades urbanas como rurales, es de un total de 80.000 personas, o sea unas 13.000 familias.

La suma - siempre hipotética - de estas comunidades y de los cementerios ascendería a un total de 130.000 individuos. No creemos que un numero conjunto de 20.500 familias o 130.000 personas represente una cifra disparatada para el poblamiento visigodo en la Península Ibérica, centrado básicamente alrededor del siglo vi. ¿Son estos datos fiables? Es una pregunta sin respuesta, pero creemos que este número aproximado no se puede rechazar, además de acercarse a los clásicos números de 100.000 a 200.000 individuos de la ya también clásica literatura historiográfica.

Queremos decir con todo lo expuesto que aunque nuestro cálculo pueda ser o verídico o hipotético, éste es posible que se acerque mucho a la realidad del número global de pobladores visigodos a todo lo largo del siglo vi y principios del VII. En efecto, es muy probable - como dice $\mathrm{J}$. Orlandis- que la estabilidad proporcionada por el reino visigodo de Toledo, incrementase los indices de población de los visigodos. Pero no hemos de olvidar los problemas planteados por pestes, enfermedades y epidemias que acabaron en Hispania con la vida de innumerables per- 
sonas, tanto de origen visigodo como hispanorromano ${ }^{14}$. La configuración del poblamiento cambió radicalmente a partir del siglo vII cuando no existió ningún problema legislativo en la fusión de hispanorromanos y visigodos.

Como conclusión podemos decir que no existe ningún dato estadístico fiable, pero que, aún siendo todos ellos hipotéticos, permiten creer que el número de pobladores visigodos de la Península lbérica no superó la cifra total de 130.000 o 150.000 individuos.

\section{Las necrópolis, factor testimonial de un hábitat cercano}

El canon XVIII del Concilio de Braga I, del año 561, dispone que los cementerios de los núcleos urbanos se sitúen extramuros de éstos, siguiendo la legislación romana: ut nullo modo intra ambitus murorum ciuislibet defuncti corpus humetur ${ }^{15}$. Esta disposición que obliga a las ciudades, también era válida para los hábitats e iglesias rurales. ¿El pueblo visigodo se rige o no por este tipo de legislación conciliar romana y entierra fuera de sus poblaciones? ${ }^{16}$. Creemos que sí, aunque ya veremos más adelante, que su aplicación es aleatoria.

Por regla general, las necrópolis, se supone se sitúan a no más de diez kilómetros a la redonda y a no menos de quinientos metros de la población rural o centro urbano, como es también el caso de los cementerios romanos. Por lo tanto, la presencia de una necrópolis cuando el

is De estos temas se han ocupado: M. BARCELO, "Les plagues de llagosta a la Carpètania, 578-649". Estudis d'historia agrària, 1978, págs. 69-84; y L. A. GARCIA MORENO, "EI campesino hispanovisigodo entre bajos rendimientos y catástrofes naturales. Su incidencia demográfica". Antiguedad y Cristianismo. III, Murcia 1986 (1987), págs. 171-187. Una visión general sobre los problemas de poblamiento y el número de individuos la aportamos en: Pedro de PALOL y Gisela RiPOL, Los godos en el occidente europeo. Ostrogodos y visigodos, siglos V-Vilt, Madrid 1988, págs. 27 y 239.

15 R. Puertas, "Terminologia arqueológica de los concilios hispanorromanos y visigodos". Actas de la primera Reunión Nacional de Arqueologia Paleocristiana, Vitoria 1966. pág. 218. Véase asi mismo la obra de conjunto de J. VIVES, Concilios visigóticos e hispanorromanos, CSIC, Barcelona-Madrid 1963, pág. 75.

${ }^{16} \mathrm{P}$. de Palot, "Clunia, 1978. Noves dades arqueologiques dels darrers segles de Clunia". Memoria de 1978 de l'Institut d'Arqueologia i Prehistória. Universidad de Barcelona. 1978, págs. 31-38 (en especial, 31 y 36). Algunos autores consideran que sí, efectivamente, el pueblo visigodo se rigio por la legislación conciliar romana; otros, sin embargo dicen que probablemente no fue asi. Personalmente creemos que siguieron con la tradición romana aunque el caso de Clunia podria ser un excepción. 
número no es muy reducido - pues en este caso puede tratarse de uno o varios enterramientos ocasionales o de un hábitat de explotación reducido o familiar - implica la existencia de una aglomeración cercana.

El problema que se plantea es que, en la mayoría de los casos, se conoce la existencia de una necrópolis y se desconoce el lugar de hábitat y viceversa; existe sólo una excepción, la del poblado y cementerio paleocristiano-visigodo de El Bovalar (Seròs, Lérida) ${ }^{17}$. Casos de conocimiento de hábitat son: el poblado visigodo de Puig Rom (Rosas, Gerona) ${ }^{18}$ y el de la ciudad de Recópolis (Zorita de los Canes, Guadalajara) ${ }^{19}$. Este desconocimiento es motivo de un grave problema para el progreso cientifico de la arqueología visigoda. En otros casos, como el de Clunia (Peñalba de Castro, Burgos), se sabe que existió un pequeño núcleo de población en época visigoda, pero de él no han quedado restos arquitectónicos civiles o religiosos, aunque sí un cierto número de tumbas. Alli se encuentran un total de veintitrés enterramientos con objetos de adorno personal, característicos de finales del siglo vi y de todo lo largo del siglo VII, agrupados alrededor de la actual Ermita de Castro, donde probablemente debió situarse el antiguo edificio de culto cristianovisigodo. Existen algunas sepulturas de la segunda mitad del siglo $v$ con elementos comparables a los de la villa romana y necrópolis de Pedrosa de la Vega (Palencia). Sobre estas tumbas se superponen las visigodas, que, deciamos anteriormente, son fechables en el siglo $\mathrm{V} /{ }^{20}$.

A pesar de lo poco avanzada que está la arqueología en la relación hábitat funerario/hábitat de poblamiento, creemos que la presencia de una necrópolis o conjunto funerario es un factor determinante en la pre-

\footnotetext{
17 Pere de PALOL, El Bovalar (Seros: Segrià). Conjunt d'epoca paleocristiana i visigotica, Lérida 1989. 28 pags., 25 figs.

18 P. de Palol. Castro hispano-visigodo de Puig Rom. Campañas de 1946 y 1947, Informes y Memorias de la Comisaria General de Excavaciones Arqueológicas, núm. 27. Madrid 1952.

${ }^{19}$ La bilbiografia de Recópolis es amplia y bastante conocida, pero las excavaciones llevada a cabo por el Dr. Lauro OImo han puesto de relieve numerosos datos nuevos sobre el amurallamiento y la basilica. Esperando su tesis doctoral, pueden consultarse las primeras conclusiones aportadas por é mismo en: "Recópolis et les habitats urbaines de la période wisigothique en Espagne", Bulletin de Liaison (AFAM), núm. 9, 1985, págs. 16-17.

$20 \mathrm{P}$. de Palol, Guia de Clunia Guias de Conjuntos Arqueológicos, Burgos, 1982 (5), pág. 28. Del mismo autor: La villa romana de La Olmeda. Pedrosa de la Vega (Palencia), Acta Arqueologica Hispánica, núm. 7, 1974. D. Campillo, et alii, "Probable aneurisma cavernoso retroocular derecho con osteoma reactivo, en el individuo número 7 de la necrópolis visigótica de Clunia (Burgos), correspondiente a los siglos v-vim, Empúries, 45-46, 19831984 (1987), págs. $342 \cdot 350,17$ figs
} 
sunción de la existencia de un poblado, de un centro de explotación rural y/o un centro religioso.

Aunque podrían traerse a colación muchos ejemplos, creemos que el de la necrópolis de El Carpio de Tajo, en Toledo, sobre el que volveremos reiteradas veces, es ejemplo cierto de este desconocimiento de relación. Toda la región donde se situa la necrópolis es fructífera en hallazgos arqueológicos que van desde la época romana hasta la Edad Media. En dicha zona se han efectuado diversos hallazgos casuales y seria muy conveniente realizar excavaciones debajo o en los alrededores de la actual Ermita de Ronda, para verificar si existe alli un centro religioso antiguo y en los alrededores un hábitat de una cierta importancia. Nos induce a pensar esto la riqueza - siempre subjetiva- de las sepulturas de la necrópolis ${ }^{21}$.

También la gran cantidad descontextualizada de hallazgos sueltos -artes menores, como fíbulas, broches de cinturón, etcétera- son índice de paso por las diferentes regiones de gentes que utilizaban objetos visigodos. Así, el puro y simple hallazgo de un broche de cinturón, puede indicar la existencia de una comunidad en las cercanías, o acaso, una reutiiización. Pero también puede indicar un "peregrinaje", un establecimiento momentáneo, una incursión, o una instalación temporal corta. Este tipo de hallazgos van siendo puntos en un mapa, que hay que ir llenando e interpretando poco a poco. El caso del Norte de la Península, en particular el de Cantabria, es un ejemplo notable, como también lo es el de la provincia de la Baetica ${ }^{22}$.

${ }^{21}$ El primer trabajo sobre esta necropolis: C. de MERGELINA, "La necrópolis de EI Carpio de Tajo", Boletin del Seminario de Estudios de Arte y Arqueología (Valladolid), XV, 1949, págs. 146-154, XXI láms. Gisela RIPOLL, «La necrópolis visigoda de El Carpio de Tajo (Toledo)", Revista de Arqueologia, 29, 1983, págs. 54-63. Posteriormente y con el mismu título publicamos la monografia completa del yacimiento en la serie aExcavaciones Arqueológicas en España», núm. 142, Madrid 1985, 254 págs., 76 figs, XIII láms. (con un apéndice de los análisis metalúrgicos de Salvador Rovira y María S. Sanz, págs. 227-254). Actualmente estamos preparando el segundo volumen pues hallamos el plano de distribución de las sepulturas de dicha necrópolis, y creemos que modifica ligeramente lo que expusimos en 1985.

22 Queremos agradecer aqui al Dr. Joaquín González Echegaray el gran numero de noticias que nos ha proporcionado acerca de antiguos y nuevos hallazgos de esta época en la región. Para determinados casos, véase: J. Gonzalez ECHEGARAY, Origenes del cristianismo en Cantabria, Instituto de Prehistoria y Arqueología "Sautuola", Institución Cultural de Cantabria, Santander 1969, 36 págs. Id., “El monacato de la España nórdica en su confrontación con el paganismo (siglos vi-viII). Semana de Historia del monacato cántabroastur-leonés, Monasterio de San Pelayo 1982, págs. 35-56. Para los recientes hallazgos de la Bética, véase la colección ingresada en el MAN, G. RIPOLL, "Bronces romanos, visigodos y medievales en el MAN 2 , Boletin del Museo Arqueológico Nacional, IV, 1986 (1987), págs. 


\section{Distribución geográfica de las necrópolis}

La distribución geográfica de las necrópolis en Hispania responde a sus origenes históricos. Si bien es cierto que el mayor número de cementerios - los más antiguos y los de mayor número de sepulturas - se encuentran situados entre los valles de los rios Duero y Tajo, ello no quiere decir que atestiguen una mayor densidad de población en dicha región. Admitimos que esa área estuvo densamente poblada en un principio, pero también hay que aceptar que el resto de la Peninsula tuvo una importante presencia de contingentes visigodos. Probablemente y como sugiere A. M. Jiménez Garnica, el haber elegido la Meseta Castellana como primer lugar de ocupación debióse básicamente a motivos económicos y estratégicos ${ }^{23}$, aunque no cabe la menor duda que la «fácil» integración en el mundo latifundista romano también debió ser un atractivo simplificador para la instalación visigoda. Entendemos que para este periodo la investigación arqueológica ha sido más prolifera en la Meseta que en otros lugares. Pero hubo también una presencia dispersa de la que son testimonio la gran cantidad de hallazgos casuales que se van localizando en diversos puntos de la geografía hispánica. Un ejemplo de la desatención que han merecido ciertas zonas geográficas lo viene a demostrar los hallazgos de cementerios visigodos de reciente descubrimiento. Asi, el de una necrópolis en los alrededores de Mérida ${ }^{24}$, también las excavaciones del conjunto cementerial de Las Huertas (Sevilla), el de El Tesorillo (Málaga) o el del Camino de los Afligidos en Alcalá de Henares (Madrid) ${ }^{25}$, 0 incluso los hallazgos, también relativamente re-

55-82, 17 figs. Actualmente estamos elaborando un amplio trabajo, pues hemos localizado una nueva colección particular, titulado: Larchéologie funéraire en Bétique, du IVe au VIIle siecle, que debe ser el objeto de nuestra tesis doctoral en la Universidad de la Sorbona* Paris IV.

A. M. JIMENEz GARNICA, "Los primeros establecimientos permanentes de visigodos en Hispania", Hispania, XLII, 1982, pags. 485-503. Articulo muy interesante pues, además de tener en cuenta los hechos históricos, analiza las fuentes y los aspectos climáticos. Aunque sus teorias pueden ser consideradas caducas, el primero que se ocupo del establecimiento de los visigodos fue REINHART, "Sobre el asentamiento ...", obra citada, págs. 124-139. Recientemente han vuelto sobre el tema: RIPOLL LOPEZ, La ocupación visigoda en época romana a través de sus necropolis (Hispania), obra citada; y A. DOMInGUez MONEDero, "Las necrópolis visigodas y el carácter del asentamiento visigótico en la Península lbérica", Actas del/ Congreso de Arqueologia Medieval Española, Huesca, 1985, Zaragoza 1986, vol. II, págs. 165-186

*Agradecemos al Dr. Jose M. Alvarez, Director del Museo Nacional de Arte Romano de Mérida, el habernos advertido de este reciente descubrimiento que permanece todavia inédito.

:F. FERNANDEZ GOMEZ, "La necrópolis tardorromana y visigoda de "Las Huertas", en Pedrera (Sevilla)". Noticiario Arqueológico Hispánico, 19, 1984, págs. 273-387, 76 figs., 7 láms. E. Serrano Ramos, et alii. "Memorias de las excavaciones del yacimiento arqueológico de "El Tesorillo" (Teba, Málaga)", Noticiario Arqueológico Hispánico, 26, 1985, págs. 119-162, IX 
cientes, son los realizados en la provincia de Huesca, consistentes en broches de cinturón de placas con mosaico de celdillas y también de algunas placas liriformes ${ }^{26}$.

El estudio topo-demográfico llevado a cabo por el Prof. Palol en 1966, es un ejemplo evidente de lo que hemos expuesto en los parágrafos anteriores ${ }^{27}$. Aunque en sus mapas deberian añadirse algunas necropolis recientemente halladas, es una sorpresa la comparación entre dos de sus mapas, el de los hallazgos casuales y el de los conjuntos funerarios. Se recensionan en este inventario alrededor de unas 45 necrópolis y unos 150 hallazgos sueltos, números que contrastan entre sí. Estos últimos, de carácter evidentemente visigodo, se distribuyen por toda la Península, incluyendo, como es natural, el actual espacio portugués.

Resumiendo la cuestión de la distribución geográfica de las necrópolis, podemos afirmar que los primeros testimonios y la correspondiente continuidad se dan en la Meseta Castellana y que desde este espacio geográfico y con muy pocos años de diferencia tuvo lugar la dispersión por toda la Península ${ }^{28}$. Los visigodos libres, dedicados a la economia

láms., 15 figs. Id., "La necrópolis de época visigoda de "El Tesorillo" (Teba, Málaga)", Actas dell Congreso de Arqueologia Medieval Española, Huesca, 1985. Zaragoza 1986, vol. II, págs. 279-295. A. Mendez Madariaga y S. Rascon Maroues. Los visigodos en alcalá de Henares. Cuadernos del Juncal, 1, Alcalá de Henares 1989. Véase la recensión de este libro que hemos realizado y que se publica en la varia de este mismo volumen de la revista Espacio. Tiempo y Forma

${ }_{26}$ Estos materiales permanecen todavia inéditos y serán publicados por Don Carlos Esco Sampériz. Desconocemos su localización exacta, pero un primer informe fue dado por él mismo en: "Le peuplement à l'époque wisigothique dans le Haut Aragon", Bulletin de Liaison (AFAM), 9. 1985, pág. 19.

27 PALOL, "Demografía y arqueología ..." obra citada., mapas VI y VII. Con el presente estudio se observa que el número de hallazgos es amplio, pero que no modifica en gran manera lo expuesto por el Prof. Palol.

${ }_{28}$ Respecto a la vieja problemática del limes, su propio iniciador, $P$. de Palol, escribió varios artículos, pero luego negó los resultados dado que este tipo de hallazgos es frecuente en otras regiones y no en particular del valle del Duero. P. de PALOL, "La necrópolis de San Miguel del Arroyo y los broches hispanorromanos del siglo IV", Boletín del Seminario de Estudios de Arte y Arqueología (Valladolid), XXXIV-XXXV, 1968-1969, págs. 93-161. Id., "Necrópolis hispanorromanas del siglo iv en el valle del Duero. III, Los vasos y recipientes de bronce", Boletin del Seminario de Estudios de Arte y Arqueologia (Valladolid), XXXVI, 1970, págs. 205-236. Seguidores de esta teoría han sido: L. CABALleRo, La necrópolis tardorromana de Fuentespreadas (Zamora). Un asentamiento en el valle del Duero. "Excavaciones Arqueológicas en España", 80, 1974, J. M. ${ }^{a}$ BLAZOUEZ, "Der Limes Hispaniens im 4. und 5. Jhr. Forschungstand. Niederlassungen der Laeti oder Gentiles am Flusslauf des Duero", British Archaeological Reports, s. i., 71, 1980, págs. 345-395. Véase el estado de la cuestión planteado por J. J. SAYAS ABENGOCHEA, "Consideraciones históricas sobre Vasconia en época bajo-imperial", La formación de Alava, 650 Aniversario del Pacto de Ariaga (1332-1982), Congreso de Estudios Históricos, Álava 1982, págs, 481-510. De reciente 
rural -fundamentalmente agrícola y ganadera - buscaron tierras aptas para sus actividades y por ello, la Meseta, con sus grandes latifundios y pocos lugares plenamente romanizados en contraposición a lo que ocurría por ejemplo en la Bética, fue un lugar apropiado. Los hallazgos en las sepulturas atestiguan que los adornos personales más antiguos, como son las fíbulas de arco y placas de técnica trilaminar y los broches de cinturón que con ellas aparecen, fechables a finales del siglo $v$ y principios del siglo vı, se localizan básicamente entre los valles de los rios Duero y Tajo, no dispersándose más allá de esta específica zona geográfica.

Lo que deseamos poner en evidencia es que por el momento tendremos que esperar un cierto tiempo para que la investigación arqueológica avance y podamos definir con mayor claridad las áreas que estuvieron más o menos pobladas durante la época visigoda y las motivaciones tanto geográficas como climáticas que indujeron a elegir los determinados lugares de asentamiento.

Las otras necrópolis que denominamos de "época visigoda", que se incluyen por tanto cronológicamente en el siglo vi, presentan una problemática diferente pero lógica, pues se trata de núcleos hispanorromanos coétanos a la llegada de los visigodos, establecidos en lugares plenamento romanizados y con unas tradiciones y concepciones profundamente romanas $\mathrm{y} / \mathrm{o}$ indígenas.

Situación topográfica de las necrópolis

Se hace dificil precisar con todo detalle la situación exacta, topográficamente hablando, de cada una de las necrópolis, pues en su mayoria los restos cemeteriales han desaparecido. El enclave geográfico de los

aparición son: A. J. DOminguez MONEDERO, "Los ejércitos tardorromanos en la Península Ibérica y el problema del pretendido "limes Hispanus" ", Revista de Guimarâes, XCIII, 1984, págs. 3-30, 2 mapas; y A. FUENTES DOMINGUEZ, La necrópolis tardorromana de Albalate de las Nogueras (Cuenca) y el problema de las denominadas "necrópolis del Duero". Cuenca 1989. Véase la recensión que hemos realizado de este libro y que se publica en este mismo volumen de Espacio. Tiempo y Forma. 
cementerios del territorio hispánico es muy semejante, en lo que al emplazamiento respecta, a los conjuntos merovingios. Muchas de las necrópolis visigodas o de época visigoda, que nos ocupan, se sitúan en la proximidad de un camino o vía de comunicación importante en la antigüedad. Siempre también proximas a un río o un arroyo pero en una situación un poco más elevada sobre el fondo del valle, en la solana de una colina o en to alto de un cerro, aunque nunca alcanzando una gran altura. Asi por ejemplo son emplazamientos típicos las necrópolis del Camino de los Afligidos (Madrid), Duratón (Segovia), El Carpio de Tajo (Toledo), Estagel (Rosellón. Francia), Herrera de Pisuerga (Palencia), etcétera. Más elevado se encuentra, a título de ejemplo, el pequeño conjunto de El Castellar (Palencia) o el de Sierra Elvira (Granada). Es muy probable que en el yacimiento del poblado de La Dehesa de El Cañal (Pelayos, Salamanca), en curso de excavación, la necrópolis se sitúe en la colina que rodea el yacimiento. Todos estos conjuntos funerarios los suponemos cercanos a un hábitat, en determinados casos rural, en otros urbano, cercanos a un vicus y a una iglesia o parroquia.

Un gran número de los cementerios que aquí nos ocupan, se encuentran absolutamente aislados, lo cual no implica que en el momento de su utilización no estuviesen en lugares con una presencia humana importante, algunos de ellos poblados desde la más remota antigüedad, otros de época bajo-imperial y otros de reciente ocupación. Existen casos muy concretos de cementerios de tradición germánica implantados sobre una construcción alto-imperial como es el caso de El Tesorillo (Málaga); bajo-imperial (?) como el de Duratón (Segovia); Aguilafuente (Segovia): sobre una villa romana tardía; al igual que ocurre con una parte del cementerio del Camino de los Afligidos que ocupa una de las zonas de las estructuras arquitectónicas de la vilia romana de El Val (Alcalá de Henares, Madrid).

Hemos podido observar que los grandes cementerios visigodos se hallan prácticamente aislados, es decir, el hábitat se desconoce y el actual poblamiento está muy alejado, por tanto no existe una pervivencia del hábitat antiguo. Así por ejemplo: El Carpio de Tajo (Toledo), Castiltierra (Segovia), Herrera de Pisuerga (Palencia), Madrona (Segovia), etcétera. Algunos de estos cementerios "clásicos" o "germánicos", pueden comportar hasta trescientas sepulturas. Suelen iniciarse cronológicamente en un período muy concreto y el momento de abandono es en todos ellos quasi contemporáneo. Tendrían un inicio de ocupación desde finales del siglo $v$ - principios del siglo $v i$ y perdurarian hasta los primeros años del siglo vil. No hemos constatado ninguna utilización anterior, y tampoco 
ninguna continuidad en la actividad sepulcral de estos grandes cementerios visigodos.

Contemporáneamente al desarrollo de estas necrópolis, existen en toda Hispania, los cementerios de tradición romano-cristiana, lo que en términos alemanes se describe como núcleos del tipo "romanisch" (cuya traducción al castellano es imposible). Su localización está siempre en función de la situación del templo. Así por ejemplo, en la Bética, el núcleo cristiano de basílica y necrópolis de San Pedro de Alcántara (Málaga), está situado junto a un arroyo pero en la llanura formada por la playa. El caso de Gerena (Sevilla), es muy semejante, al que venimos de citar, con una basilica, cubierta por sepulturas que se extienden tanto en el interior como en el exterior del espacio cultuai. También se da este fenómeno de agrupación de sepulturas en/y alrededor del templo, en un gran número de yacimientos de la Lusitania como son Alconétar, Casa Herrera, El Germo, Ibahernando y Torre de Palma, en Portugal. Estos grupos hispanos se rigen por su tradición romana y no por la germánica, con la que conviven pero no se mezclan. Tendremos que esperar la llegada de la supuesta unidad confesional para que estos dos grupos bien diferenciados se interrelacionen y se conviertan aparentemente en uno.

En este momento aparecerán grupos de necrópolis de veinte a cincuenta sepulturas, a veces más, que se integran en un recinto eclesiástico, como es el caso de muchas iglesias rurales, siempre correspondientes a la sociedad hispanorromana y nunca a individuos visigodos, cuya diferenciación entre necrópolis e iglesia es muy patente arqueológicamente. El canon XVIII del Concilio de Braga I, celebrado en el año 561, es interesante para el estudio que nos ocupa: De corporibus defunctorum. (De corporibus hominum intra baselicas sanctorum nullatenus sepelliendis.) Item placuit, ut corpora defunctorum nullo modo intra basilicam sanctorum sepeliantur, sed si necesse est de foris circa murum baselicae usque adeo non abhorret. Nam si firmissimum hoc previlegium usque nunc retinent civitates, ut nullo modo intra ambitus murorum cuiuslibet defuncti corpus humetur, quanto magis hoc venerabilium martyrum debet reverentia obtinera ${ }^{29}$.

Como bien han recalcado algunos autores, entre ellos Puertas Tricas $^{30}$, se deduce de este texto que enterrar dentro de las basilicas

z' VIVES, Concilios visigóticos..., obra citada, pág. 75.

${ }^{30}$ R. Puertas ThICAS, Iglesias hispánicas (siglos IV al VIII). Testimonios literarios, Madrid 1975, pág. 90 
hasta mediados del siglo vi era un hecho habitual -al menos por parte de los hispanorromanos - y que a partir de esta fecha se debería realizar fuera de las basilicas. El texto afirma también, como veiamos más arriba, que la legislación conciliar aconseja que los cementerios se sitúen fuera de los recintos urbanos, como quedaba ya indicado en el código teodosiano: Omnia quae super terram urnis clausa vel sarcophagis corpora detinentur extra urben delata ponantur ${ }^{31}$. No obstante parece que los fieles - aunque no se sabe si se trataba de personajes eclesiásticos- no respetaron tal prescripción conciliar y seguimos encontrando durante el siglo vil cementerios que ocupan el ámbito basilical, tanto interno como externo. La fecha de construcción de la iglesia y la fecha de utilización de ésta como ámbito para celebrar las liturgias, a veces coincide, pero por regla general, la función funeraria se realiza con posterioridad cronológica a la eclesiástica. Un ejemplo en el que este hecho queda bastante claro, podría ser el citado anteriormente de San Pedro de Alcántara (Málaga).

Los conjuntos fechados desde el siglo VI hasta principios del siglo VIII, testimonian que la legislación conciliar establecida por el canon XVIII del Concilio de Braga I, no se respetó, pues existía una inclinación por parte de los fieles en enterrarse cercanos o en el interior del ámbito basilical.

Un ejemplo donde iglesia y necrópolis, ambas conocidas por la arqueologia, se encuentran separadas -es decir, los fieles no se entierran en el ámbito basilical- es el de Segóbriga (Cuenca), cuya iglesia se conoce bajo el nombre de Cabeza de Griego. En dicha iglesia se hallan sepultados los obispos de la ciudad o personajes relevantes de la vida eclesiástica, sin embargo el pueblo se entierra en un espacio funerario reservado a este fin y no lejos de dicha basilica. ¿Existe en el espíritu de esta comunidad la necesidad o conciencia de respetar lo prescrito por el canon conciliar? Muy probablemente no, puesto que el Concilio de Braga del año 561 fue provincial y asistieron únicamente ocho obispos gallegos. Es lógico pensar que éste obliga a los provinciales de la Gallaecia, pero Segóbriga es evidente que no pertenece a esta provincia. Sin embargo, el canon permite entrever que se trata de una cuestión quizá a nivel más general; a pesar de que los acuerdos tomados en los concilios no llegaban a ser transmitidos a las comunidades rurales de las diferentes provincias y por ello los fieles, con o sin conocimiento de causa, seguian enterrándose a veces junto al centro eclesiástico, creyendo estar más

"Texto citado por E. SALIN. La civilisation mérovingienne d'apres les sépultures, les textes et le laboratoire. II.-Les sepultures, Paris 1952, pág. 33. 
cerca de la protección y de la vida religiosa del espacio sagrado. Esta práctica será definitiva a partir del siglo XI.

\section{Disposición de las sepulturas en el ámbito cementerial}

"Cuanto más romanizados estaban los bárbaros, más se pierde la ordenación de los cementerios", escribió Salin ${ }^{32}$, y así se constata en la Península ibérica. Los pocos cementerios caracteristicos de la "Reihengräberzivilisation" " ${ }^{33}$, son fechables todos ellos en el siglo vI. A medida que la unificación se hace palpable en las gentes pobladoras de Hispania, hispanorromanos y visigodos, este sistema de ordenación de las sepulturas en los cementerios, se pierde, a excepción de algunos casos bien documentados como por ejemplo el de Piña de Esgueva (Valladolid). Tan sólo contamos con cuatro verdaderos planos de grandes necrópolis puramente visigodas donde se puede observar el fenómeno de los cementerios de sepulturas alineadas. Se trata de Duratón (Segovia) ${ }^{34}$, Castiltierra (Segovia), El Carpio de Tajo (Toledo) ${ }^{35}$ y Estagel (Rosellón francés) ${ }^{36}$.

En estos cementerios la distribución de las sepulturas se hace por grupos y están ordenadas de tal manera que forman calles de circulación y espacios, que quizá en determinados casos podrian ser considerados como lugares de reunión. Esta organización la encontramos también en los cementerios de tradición romana, como es el ejemplo - de época

32 E. Salin, La civilisation mérovingienne d'aprés les sepultures, les textes et le laboratoire. IV.-Les croyances, Paris 1959, pág. 455.

${ }^{33}$ Sobre los cementerios de sepulturas alineadas, en epoca de las migraciones, véase el articulo del que fue uno de los primeros en tratar este tema: J. WERnER, "Zur Entstehung der Reihengräberzivilisation", Archaeologia Geographica, 1. Hamburgo 1950-1951, págs. 23-32.

${ }^{34}$ Vease la monografía de Duratón: A. MOLInero Perez. La necropolis visigoda de Duratón (Segovia). Excavaciones del Plan Nacional de 1942 y 1943. Acta Arqueológica Hispánica, núm. 4, 1948.

${ }^{35}$ El Sr. Casamar tuvo la amabilidad de proporcionarnos un plano de la necropolis de Castiltierra, que le habia sido entregado por la señora $M{ }^{2}{ }^{2}$ Teresa Camps, hija de Emilio Camps Cazorla. Dicho plano pretendemos estudiarlo, al igual que el de El Carpio de Tajo. Por el momento para esta ultima necropolis debe uno dirigirse a su monografia: RIPOLL, La necrópolis de El Carpio de Tajo.... obra citada.

36 Varias son las publicaciones o articulos sobre la necrópolis de "Las Tumbas", en Estagel, vease aquella que reproduce el plano: R. LANTIER, "Le cimetiere wisigothique d'Estagel (Hautes-Pyrénées)", Gallia, 7, 1949, págs. 55-80. 
ligeramente anterior- de Pedrosa de la Vega (Palencia). Los enclaves familiares pertenecen siempre a grupos de la misma generación y al mismo rango. Así se demuestra en muchas necrópolis, como es el caso recientemente estudiado por $\mathrm{H}$. Reimer, de Daganzo de Arriba (Madrid) ${ }^{37}$. o también el del Camino de los Afligidos (Madrid), donde podrian llegar a determinarse claramente unos grupos familiares ${ }^{38}$. Todas las sepulturas además de seguir una ordenación espacial, siguen una orientación Este-Oeste, que fue probablemente adoptada cuando los godos se acogieron al cristianismo ${ }^{39}$ y abandonaron definitivamente los pocos casos existentes de incineración por una utilización generalizada de la inhumación. La orientación de las sepulturas variará siempre según la época del año en que se haya enterrado al individuo e indudablemente según las características físicas, geológicas y topográficas del terreno. Las desviaciones de las sepulturas en un cementerio son un fenómeno habitual, aunque esta desviación es siempre muy leve y en muy pocos casos llega a alcanzar la posición Norte-Sur ${ }^{40}$. Cuando esta orientación está perfectamente definida, como es el caso de algunas sepulturas de la necrópolis de Segóbriga (Cuenca), se trata entonces de inhumaciones posteriores, con una cierta probabilidad de época árabe.

En las necrópolis de tradición romano-cristiana instaladas en ámbitos eclesiales, que mencionábamos anteriormente, las sepulturas ocupan

${ }^{37} \mathrm{H}$. Reihmer, presentó en la Semana de Estudios Visigóticos de la Fundación Pastor (Madrid), celebrada en octubre de 1985, un interesante estudio sobre esta necrópolis, pero no aparece publicado en las actas. Algunas ideas de su tesis doctoral fueron expuestas en: H. REIHMER. "Soziale Schichten im Westgotenreich von Toulouse und Toledo. Einige Bemerkungen zu den westgotischen Freien", Ethnographische-Archäologische Zeitschritt, 25, 1984, pág. 484. El plano de la necrópolis fue publicado por S. Fernandez Godin y J. Perez OE BARRADAS, "Excavaciones en la necrópolis visigoda de Daganzo de Arriba (Madrid)", Memorias de la Junta Superior de Excavaciones y Antigüedades, 114, 1931, lám. 1.

38 Méndez Madariaga y Rascon Marques, Los visigodos en Alcalá ... obra citada, págs. 172-176

${ }^{39}$ Este tema ha sido ampliamente tratado por H. Hubert, Les Germains, Paris 1952. págs. 113-114. SALIN, La civilisation mérovingienne... II. Les sépultures, obra citada., págs. 2.11. E. A. ThOMPSON, The visigoths in the time of Ulfila, Oxford 1966. Un resumen general ha sido realizado por Young, "Paganisme, christianisation...", obra citada, págs. 15-16.

40 SalIN. La civilisation mérovingienne ... II. Les sépultures, obra citada, págs. 190-193. Véase del mismo autor Le Haut Moyen Age en Lorraine d'aprés le mobilier funéraire. Paris 1939. El investigador francés se interesó por los problemas de orientación en los cementerios e intentó demostrar cómo los pueblos germánicos tuvieron una gran preocupación por la perfecta orientación de las sepulturas, que él relacionaba con el culto al sol. Los eruditos de la alta Edad Media conocian los cálculos necesarios que precisaban las aplicaciones geográficos y topográficas, y sabemos que Beda el Venerable hace referencia extensamente a ello: Libellus de mensura horologii. Patrologia Latina de Migne, t. XC, col. 953 y 954. Salin propone que la orientación de las tumbas es el resultado de una medición hecha a la salida del sol, antes de ser excavada la fosa de los difuntos. 
todo el territorio externo e interno de la estructura arquitectónica, aunque siempre se deja libre la zona del ábside donde se oficiaba. En las basilicas de ábside contrapuesto, el ábside occidental puede estar ocupado por una sepultura, como en los casos de Casa Herrera (Badajoz) y Torre de Palma (Monforte, Portugal), sólo por traer un par de ejemplos a colación. La función martirial de estos ábsides occidentales está todavía por demostrar y plantea en este momento dificultades de estudio ${ }^{41}$. Evidentemente la instalación de las sepulturas es posterior a la construcción del edificio, pues el ábside occidental estaba destinado originariamente a una función litúrgica y no funeraria. Consideramos que el que aparezcan enterramientos en el interior de estos ábsides no tiene una significación particular, hecho que se constata también en el Norte de África. Las capillas funerarias sin esa significación particular, fueron analizadas en su día por N. Duval: Orléansville, Tipasa (capilla de Alejandro), Matifou, Belalis Mayor I, Cartago (Damus el Karita), Sabratha I, y las probables de Bulla Regia I, Belalis Mayor II, Cartago-Dermech III, Mididi, Thélepte III, lunca III y $\mathrm{Hr}$ Goraat ez $\mathrm{Zid}^{42}$. En todos estos templos se constata una función funeraria del ábside occidental pero ésta es siempre de época posterior a la construcción basilical, y creemos que en los casos hispánicos, nos encontramos ante el mismo fenómeno. El hecho de que se sitúen sepulturas tanto en el exterior como en el interior de la basílica atestigua una necesidad por parte de los fieles de enterrarse lo más cerca posible del recinto sagrado, hecho al que ya aludiamos precedentemente, intentando respetar siempre la orientación habitual Este-Oeste, hecho éste que viene simplificado por la propia orientación constructiva del templo.

Señalización de las sepulturas

El cómo, dónde y por qué de la señalización de las sepulturas dentro de los conjuntos cementeriales visigodos ha sido siempre una incógnita para

4. Este tema ha interesado a aigunos investigadores y actualmente se esta lievando a cabo una tesis doctoral por parte de Pierre Dourthe de la Universidad de la SorbonaParis IV.

42 Noël Duval, Les églises africaines à deux absides. Recherches archéologiques sur la liturgie chrétienne en Afrique du Nord, París 1973, 2 vols. Veanse del $2^{\circ}$ vol. las páginas 335-338, referidas a los casos norteafricanos con sepulturas en el ábside occidental. También en el $2^{\circ}$ vol. págs. 377-395, donde se exponen las conclusiones del Norte de África y se recensionan todos los casos conocidos en la Península lbérica, a excepción de la basilica de El Bovalar (Lérida) y Huerta de Nicomedes (Gerena, Sevilla). 
el investigador. Y sigue siéndolo. Muy pocos son los datos acerca de esta problemática, pero a pesar de ello los expondremos e intentaremos llegar a una conclusión.

Las tumbas de las necrópolis merovingias suelen estar señalizadas por medio de estelas, amontonamientos de piedras en la cabecera o simplemente una piedra sobresaliente en la misma zona de la cabecera. Ejemplos típicos de esta costumbre son las necrópolis de Vorges (Aisne) ${ }^{43}$ y de Roissard (Isère) ${ }^{44}$. Tanto en los cementerios merovingios como en los visigodos, las sepulturas se reutilizan y en ellos se encuentran casos de varias inhumaciones sucesivas. Por ello para localizar la tumba - por regla general familiar - se precisa una señalización externa. Pero las particularidades de las necrópolis con carácter visigodo del territorio hispánico, no incluyen senalizaciones como las merovingias. Algunos autores "suponen" que estos indicativos se basaban, también en la Peninsula, en amontonamientos de piedras ${ }^{45}$, quizá por ello los arqueólogos no se den cuenta de este fenómeno durante el proceso de excavación, aunque es un poco dudoso. Molinero Pérez, de forma general, dice que las sepulturas de Duratón (Segovia), estaban indicadas por medio de estelas en la cabecera, en los pies o en ambos extremos ${ }^{46}$, pero leyendo con minuciosidad su monografía, sólo se especifica un solo caso ${ }^{47}$. Se trata de la sepultura $n^{\circ} 129$, en cuya cabecera se encontró una estela. Ahora bien, ¿se trata de una estela de señalización, o bien es tan sólo una reutilización a la altura de la cabecera? El único caso fiable que conocemos de una super-estructura de señalización es el de Amusquillo de Esgueva (Valladolid) ${ }^{48}$. Según los autores, una estela señalizaba el lugar de la tumba. Se trata de un bloque plano de forma redondeada con apéndice para introducir en el suelo. Un ejemplo semejante fue hallado en la llamada necrópolis de Alcazarén (Valladolid), paralelizado con el procedente de Puras de Villafranca (Burgos) ${ }^{49}$. Creemos que ambos ha-

4.3 Marie-Pascale FlECHE. "La nécropole mérovingienne de Vorges (Aisne)", Revue Archéologique de Picardie, 3/4, 1988, págs. 89-125, 66 figs.

${ }^{4} \mathrm{M}$. Colardelle. Sépulture et traditions funéraires du vau xill siécle ap. J. C. dans les campagnes des Alpes francaises du Nord (Drome, Isere. Savoie. Haute-Savoie), Grenoble 1983, pág. 40.

${ }^{45}$ M. Beltran Lloris, "Memoria de las excavaciones arqueológicas del Alto de la Barrilla (Cuarte, Zaragoza), 1975", Noticiario Arqueológico Hispánico, 6, 1979, pág. 570.

* A. MOLINERO PEREZ, "La necrópolis visigoda de Duratón. Materiales de tipo bizantino", Cronica del IV Congreso Arqueologico del Sudeste Español. Elche, 1948. Cartagena 1949, pág. 498.

4) MOLINeRo PeREz, La necrópolis visigoda de Duratón..., obra citada, pág. 48.

${ }^{44}$ J. BARRIENTOS. "Hallazgo de una nueva necrópolis visigoda (Amusquillo de Esgueva)", Boletin del Seminario de Estudios de Arte y Arqueologia (Valladolid), 8-9, 1934-1935, pág. 416. fig. 6

${ }^{49}$ G. Nieto Gallo. “Exploraciones arqueológicas en la provincia: la necrópolis visigoda en 
llazgos, corresponden a la época medieval. Otro ejemplo que debe ser mencionado aqui es el proporcionado por la excavación de Villel de Mesa (Guadalajara) ${ }^{50}$. En dicho cementerio se encontró una sepultura con indicación de la cabecera en "piedra de toba". Según la relativamente reciente excavación llevada a cabo en el Camino de los Afligidos (Madrid), también alli se localizaron amontonamientos de piedras sobre las sepulturas que son interpretadas como elementos de señalización ${ }^{51}$. Pero todas estas indicaciones son muy someras y no auguran una sólida interpretación.

Por medio de los textos y de la excavación llevada a cabo por Raymond Lantier en la necrópolis visigoda de Estagel (Rosellón, Francia), podemos llegar a más amplias consideraciones. Lantier afirma que en dicho cementerio las sepulturas estaban senalizadas con bloques de piedra cuadrangulares, a veces redondeados en la parte sobresaliente, o bien con ladrillos fijados en la cabecera o en los pies de la tumba ${ }^{52}$. Dice que por regla general estas estelas han desaparecido debido al acondicionamiento del terreno para la agricultura. Pero la excavación de Estagel, proporciona algunos datos más que Lantier ya habia recalcado ${ }^{53}$. Las sepulturas $n^{\circ} 28,179,184$ y 189, presentaban en el momento de su excavación una obra protectora sobre la tumba. Este tipo de construcciones, el propio Lantier, las identifica con la basilica super hominem mortuum, citada por la Ley Sálica, o bien con el mandalus.

El texto que sigue a continuación, Lex Salica, tit. LVII, especifica el castigo que se impondrá a aquellos que destruyan la estructura, despojen y violen una sepultura, to cual indica indirectamente que existian unas construcciones sobre las tumbas: Si quis aristatonem, hoc est staplum super mortuum missum capulaverit, aut mandualem, quod est structura, sive selave, qui est ponticulus, sicut more antiquorum faciendum fuit, qui

Alcazaren (Valladolid)", Boletin del Seminario de Estudios de Arte y Arqueologia (Valladolid), 12, 1945-1946, págs. 149-151, 1 fig., I lam. Para el hallazgo de Villatranca, véase: L. Huidobro Senna. Contribución al estudio del arte visigótico en Castilla, Valladolid 1916, pág. 76, figs. 31 y 32 .

"M. M. Martin Rocha y A. M. Elorraleta Lacy. "El cementerio visigodo de Villel de Mesa (Guadalajara)", Cuadernos de Historia Primitiva del Hombre, 11, 1947, pág. 55. $112 \cdot 114$.

Mendez Madariaga y Rascon Maroues, Los visigodos en alcalá ..., obra citada, págs.

b2 R. LANTIER, "Le cimetiere wisigothique d'Estagel (Pyrénées-Orientales), Musées de France. 2, 1950, pág. 46.

53 R. LANTIER. "El cementerio de Estagel y los cementerios visigodos de Galia y España", Crónica del IV Congreso Arqueológico del Sudeste Español Elche, 1948, Cartagena 1949, págs. 520-521. 
hoc destruxerit, aut mortuum exinde expoliaverit, et unaquaque de istis DC. den. qui faciunt sol. XV. culp. iudicetur ${ }^{54}$.

La Lex Salica, tit. LVII, es interesante, pues en ella se habla de estructuras en forma de basilica que se situan sobre la sepultura: Si quis domum in modum basilicae factam super hominem mortuum expoliaverit, ICC. den. qui faciunt sol. XXX. culp. iud. excepto capitali et dilatura ${ }^{55}$.

Estos textos permiten conocer la existencia de una señal o marca externa en la superficie del conjunto cementerial. Pero, ¿porqué en Estagel se encuentran restos de posibles super-estructuras tumbales y no ocurre asi en las necrópolis del territorio hispánico? Quizás puedan responder a ello algunos textos que hacen referencia a los castigos que recibían los violadores de sepulturas e incluso los destructores de ellas. He aquí el texto del canon XLVI, del IV Concilio de Toledo, celebrado en el año 633: De clericis sepulchra demolientibus. Si quis clericus in demoliendis sepulchris fuerit deprehensus, quia facinus hoc pro sacrilegio legibus publicis sanguine vindicatur, oportet canonibus in tali scelere proditum a clericatus ordine submoveri et poenitentiae triennium deputari ${ }^{56}$. Este canon, al igual que los textos anteriormente citados y los que siguen a continuación, demuestran que existía la práctica habitual de destruir pues los sepulcros y ello quiere decir al mismo tiempo, que en cierto modo debió ser costumbre - por parte de determinados sectores sociales- destruir las sepulturas.

De las leyes visigodas, que siguen en la línea específica de los canones conciliares, aportamos el siguiente texto concerniente a la serie de Leges Visigothorum, XI, 2, 1: De violatoribus sepulcrorum: Si quis sepulcri violator extiterit aut motuum expoliaverit et ai aut ornamenta vel vestimenta abstulerit, si liber hoc fecerit, libram auri coactus exolvat heredibus et que abstulit reddat. Quod si heredes non fuerint, fisco nostro cogatur inferre et preterea $C$ flagella suscipiat et insuper flammis ardentibus exuratur, redditis nihilominus cunctis, que visus est abstulisse ${ }^{57}$.

El otro texto de las Leges Visigothorum, XI, 2, 2, cita especificamente el robo de un sarcófago, hecho interesante para conocer los diferentes tipos

\footnotetext{
s4 Lex Salica, tit. LVII, De corporibus expoliatis, 3. Edición de F. WALTER, Corpus iuris Germanici antiqui, Berlin 1824, t. I, pág. 77

ss Lex Salica, tit, LVII, De corporibus expoliatis, 7. Edición de WALTER, Corporibus iuris ..., obra citada, pág 78 .

${ }_{56}$ VIVES, Concilios visigoticos..., obra citada., pág. 207.

${ }^{57}$ Leges Visigothorum, XI, 2, 1, De violatoribus sepulcrorum. M.G.H., Leges Visigothorum, I, pág. 403
} 
de sepulturas y cómo se practicaba la violación en cada una de ellas: i quis mortui sarcofagum abstulerit, dum sibi vult habere remedium, XII solidus iudice insistente heredibus mortui cogatur exolvere. Quod si domino iubente servus hoc admiserit, dominus pro servo suo conponere non moretur. Servus vero. si ex sua voluntate hoc admiserit, nihilominus $C$ flagella suscipiat, et quod tulerat et loco et corpori propio reformetur ${ }^{58}$.

El texto de los Digesta, XLVII, 12, especifica cuales serán los castigos que se otorgaran a los violadores de las tumbas, tanto por medio de las armas como sin ellas: Adversus eos qui cadavera spoliant praesides severius intervenire, maxime sin manu armata adgrediantur, ut, si armati more latronum id egerint, etiam capite plectantur, ut divus Severus rescripsit. si sine armis, usque ad poenam metalli procedunt ${ }^{59}$. El texto correspondiente a la Lex Salica. LVIII, I, es también muy explicito en este sentido: Et antigua lege, si corpus iam sepultum exfodierit, et expoliaverit, wargus (dejectus et expulsus) sit usque in diem, qua cum parentibus ipsius defuncti convenerit, et ipsi pro eo rogent, ut inter homines liceat ei accedere; et quicunque antea ei aut panem, aut hospitale, sive uxor sua, sive proxima, ei dederit, $D C$. den. qui faciunt sol. XV. culpabilis iudicetur ${ }^{60}$.

Es evidente que estos textos muestran cómo la violación de las sepulturas era habitual, y su interdicción debía ser reiterada innumerables veces. Sin embargo, estos textos no nos dicen explícitamente, si las sepulturas estaban o no señalizadas. O acaso por ese hábito de robar las sepulturas, éstas no tenian señalizaciones externas, y por ello leyes y canones conciliares, llaman continuamente la atención sobre este hecho. Es una pregunta cuya respuesta es dificil. Quizá la minuciosa excavación de una necrópolis aportaría nuevas luces al tema.

Otro dato de interés es la existencia en Estagel, de muros que rodeaban los conjuntos sepulcrales de carácter familiar ${ }^{61}$. Asi en dicho cementerio las tumbas 182, 183 y 184, correspondientes a dos adultos y un niño, se aislaron con un muro de piedra. En la Península no hemos constatado ningún caso como el de Estagel, pero no por ello debemos dejar de lado la posibilidad de que existiese algún tipo de estructura

${ }^{58}$ Leges Visigothorum, XI, 2, 2, De violatoribus sepulcrorum, M.G.H., Leges Visigothorum, I. pag. 403.

${ }^{59}$ Digeste, XLVII, 12. Edición de T. MOMmSEn, Corpus iuris civilis, I, Digesta, Berlin 1928, pág. 837

6o Lex Salica, tit. LVIII, I, Versión Herold, Edición WALTER, Corpus iuris ..., obra citada. pág. 77 .

${ }^{61}$ LANTIER, "Le cimetiére wisigothique d'Estagel", obra citada, pág. 71. 
perecedera que rodease los grupos familiares, delimitando así las propiedades funerarias hereditarias de generación en generación y marcando al mismo tiempo los espacios de circulación o aquellos destinados a la celebración de reuniones, en el mismo ámbito del cementerio.

A pesar de estos pocos elementos arqueológicos, creemos que las sepulturas o bien eran visibles dentro del espacio cementerial o bien quedaban señalizadas una vez se habia llevado a cabo la ceremonia funeraria. Suponemos que en muchos casos las sepulturas con estructuras arquitectónicas sobresalientes - también los sarcófagos-- no quedaban totalmente ocultas por la tierra, y dada la variedad constructiva no deberian precisar de una señalización muy perfeccionada. Nos inclinamos a pensar, con más seguridad, aunque sea hipotética, que las sepulturas en todo el campo funerario estaban señalizadas por medio de estructuras de madera sencillas o complejas (cruces, verdaderas construcciones, simples palos, pequeños túmulos de tierra, plantas, etcétera) ${ }^{62}$. De otra forma es dificil imaginar como los individuos recordarian el lugar de inhumación familiar de las precedentes generaciones.

\section{Rituales funerarios}

Tras los datos que hemos expuesto en los apartados precedentes, y pensando tratar los diferentes tipos de inhumación y la arquitectura funeraria en otro lugar, podemos pasar ahora a un rápido intento de distinguir en los cementerios y particularmente a través de las sepulturas, unos rituales funerarios. Estos rituales sólo pueden ser comprendidos si se ponen en relación con las concepciones escatológicas del momento, es decir, el por qué de la muerte y los enterramientos, y su relación con el espacio de los vivos. Por ello debemos considerar la tumba como un “intervalo" entre la muerte del hombre y la resurrección ${ }^{63}$, si desde un principio tomamos en cuenta esta consideración, estamos entonces defi-

6i No tratamos aquí toda la problemática suscitada por las cruces caladas, que se tienen como señalizaciones de sepulturas, pues no creemos que asi sea, vemos más en estas piezas de escultura, remates hastiales de edificios arquitectónicos, tal como demuestra el hallazgo in situ de la iglesia visigoda de Vera Cruz de Marmelar (Portugal) y los recientes descubrimientos llevados a cabo en la villa hispano-visigoda de Plá de Nadal en Ribarroja del Turia (Valencia).

t.3 P. A. FEVRIER, "La tombe et l'au delá", en: Les temps chrétien, París 1984, págs. 164-183. 
niendo no sólo una realidad filosófica, sino también histórica y arqueológica. La realidad que nosotros pretendemos estudiar ocurre en un complejo mundo y un ámbito geográfico muy amplio, como es la Península Ibérica en época visigoda. Evidentemente se entremezclan en esta civilización diversos caracteres, que a veces incluso nos recuerdan las creencias germánicas - religiosas y mitológicas-- pero con más frecuencia las bases establecidas por el cristianismo de la baja-romanidad. El pueblo visigodo inmerso en una sociedad romana y católica de la que ha adoptado un sinfín de rasgos de su cultura, estará influido en lo que a «tiempo", "alma" y "muerte" se refiere, llegando a asimilar sus concepciones.

El porqué de una tumba o sepultura es un hecho fácil de responder, el cuerpo físico debe tener un lugar de descanso o espera, es decir, una infraestructura material para poder pasar a la vida del más allá, estado eterno del hombre ${ }^{64}$. Por ello la paralización del cuerpo, o to que es 10 mismo, la prolongación de la vida terrestre, se lleva a cabo dentro de la sepultura y debe ser acompañado de sus bienes personales (adornos) para pasar al paraiso celestial o a la vida de ultratumba ${ }^{65}$. Tan sólo aparecen objetos de adorno personal, pues los nuevos sistemas de valores manifestados durante el Bajo Imperio ponen en evidencia el status inmaterial del alma ${ }^{66}$, es decir, ésta no necesita estar acompañada en ese "intervalo" por unos depósitos funerarios específicos. Muchas y diferentes son las concepciones del alma que configuraron las creencias de la Antigüedad Tardia ${ }^{67}$. Algunas de estas ideas quedaron transcritas también en el Concilio de Toledo I, de los años 397 o 400, cuyo canon $X X \mid$ de cuando termina la constitución del concilio toledano, dice asi: ...Resurrectionem vero futuram humanae credimus carni: animan autem hominis non divinam esse substantiam aut Dei partem, sed creaturam

64 G. SANDERS, "La tombe et l'eternité: categories distinctes ou domaines contigus? Le dossier épigraphique latin de la Rome chrétienne", en: Le temps chrétien, Farís 1984, págs. 186-218, véase sobre todo pág. 206.

65 A. VARAGNAC, Civilisation traditionelle et genres de vie, Paris, 1948, pág. 217.

os A. DieRKENS, "Archeologie funéraire et christianisme à l'époque mérovingienne. Pour une interpretation plus critique", Bulletin de Liaison (AFAM), 4, 1981, págs. 6-8. Se puede también consultar el articulo de Young. "Paganisme, christianisation, ...", obra citada, págs. 5-81.

${ }^{67}$ F. Cumont, Lux Perpetua, Paris 1946, pág. 6. Las tres categorias son: "aquella que se considera que el alma vive en la tumba como en una casa, otra que cree que el alma se reune con las otras en un lugar subterráneo y la última que considera que el alma abandona el cuerpo y vuela a un paraiso terrestre". Reléase por ejemplo el Diálogo de Platón: Fedón o la inmortalidad del alma. Son interesantes también las observaciones hechas en el Dictionnaire d'Archéologie Chrétienne et de Liturgie de F. CABrol y H. LECLERCO, s.v.: mort, col. 38 y s.v.: âme, col. $1475,1477-1478,1522-1523,1537-1538,1551$ 
dicimus divina voluntate creatam ${ }^{68}$. En él se afirma la creencia en la resurrección de la carne.

En el año 561 se celebró el Concilio de Braga I, donde se especificaron las propuestas contra la herejía de Prisciliano y con ello se pueden comprender las concepciones sobre el alma, a mediados del siglo vi:

$\mathrm{V}$.-Si quis animas humanas vel angelos ex Dei credit substantia extitisse, sicut Manicheus et Priscillianus dixerunt, anathema sit.

VI.-Si quis animas humanas dicit prius in caelesti habitatione peccasse et pro hoc in corpora humana in terra dejectas, sicut Priscillianus dixit, anathema sit.

IX.-Si quis animas et corpora humana fatalibus stellis, credit astringi, sicut pagani et Priscillianus dixerunt, anathema sit.

$X$ - - Si quis duodecim signa de sideribus quae mathematici observare solent, per singulas animi et corporis membra disposita credunt et nominibus patriarcharum adscripta dicunt, sicut Priscillianus dixit, anathema sit ${ }^{69}$.

No es nuestra pretensión hacer aquí toda una tesis sobre la concepción del alma, pero nos ha parecido interesante exponer estos textos, pues demuestran cómo la tumba es la materialización de la esperanza en la resurrección concebida como "intervalo", al que aludiamos antes, entre el tiempo de vida y el tiempo de resurrección. Desarrollar aquí todas las concepciones y transcribir los textos que se refieren al alma, seria imposible, pues los Padres de la Iglesia hacen una alusión constante a este tema teológico ${ }^{70}$. Sin embargo, se constata que en época visigoda existe una creencia absoluta en el alma y una esperanza de resurrección que induce a los hombres a enterrarse en grupos familiares, con unos adornos personales y una sólida arquitectura funeraria, para albergar al cuerpo hasta el momento de la resurrección ${ }^{71}$.

id Vives, Concilios visigóticos..., obra citada, pág. 26.

69 VIVEs, Concilios visigóticos..., obra citada, pág. 68. Sobre el dogma de la resurrección, véase el importante articulo publicado por H. I. MarRou, "Le dogme de la resurrection des corps et la theologie des valeurs humaines selon l'enseignement de Saint Augustin", Revue d'Etudes Augustiniennes, 12, 1966, págs. 112-136. (Nosotros hemos utilizado el mismo texto reproducido en Patristica Sorbonensia, 9, Paris 1976, págs. 429-455). Ver págs. $432-436$.

Ver por ejemplo et articulo de J. M. GIRARD, "Influence sur la perspective de la mort dans l'appréciation du temps chez Saint Augustin", en: Le temps chrétien, Paris 1984, págs. 383-390. La bibliografía es muy abundante. Prácticamente todas las obras de H.-I. Marrou, contienen amplia información sobre el tema.

${ }^{1}$ Sobre el problema de la muerte en general y a traves de las distintas épocas, se 
Muy pocos son los testimonios arqueológicos que corroboran todas estas creencias o que permiten hace un estudio profundo de los rituales funerarios. En Estagel (Rosellón francés), R. Lantier, descubrió algunos elementos interesantes para el estudio de las prácticas rituales funerarias ${ }^{72}$. Cercanos a las sepulturas se encontraron restos de carbón que testimoniarian el haberse encendido fuegos relacionados con ceremonias rituales en las concesiones familiares o áreas, a las que aludíamos anteriormente. Este tipo de espacios a los que se refiere Lantier, existen también en El Carpio de Tajo (Toledo) y en Duratón (Segovia), y se observan en el reciente plano descubierto de Castiltierra (Segovia), pero no nos atrevemos a afirmar que estuviesen destinados a utilizarse como lugares de reunión ritual. Por otra parte existen algunos textos y éstos son muy estrictos, que prohiben la celebración de misas o velatorios en los conjuntos cementeriales. Todos estos textos son, o bien muy antiguos, o bien muy tardíos, pero creemos que es importante citarlos, pues en algunos casos estaban todavia vigentes y en otros son tributarios de las prácticas que se llevaban a cabo anteriormente por parte de los paganos en ritos populares y no en ritos oficiales. Así por ejemplo dos cánones del Concilio de Elvira, celebrado en el año 300 o 306. El canon XXXIV dice: Ne cerei in ciminteriis incendantur. Cereos per diem placuit in cimiterio non incendi, inquietandi enim sanctorum spiritus non sunt. Qui haec non observaverint arceantur ab ecclesiae comunione ${ }^{73}$. Se entiende pues a partir de este canon que la expulsión de la iglesia será inmediata para aquellos que durante el dia celebren ceremonias con cirios en el ámbito cementerial.

También del Concilio de Elvira, es explícito el canon XXXV, que dice: Ne feminae in cimiteriis pervigilent. Placuit prohiberi ne feminae in cimiterio pervigilent, eo quod saepe sub obtentu orationis latenter scelera conmittant ${ }^{74}$. El que se prohiba con este canon que las mujeres velen a los muertos en los cementerios, porque pueden cometerse graves delitos de forma oculta, demuestra al mismo tiempo que los rituales funerarios no consistían sólo en simples velatorios, sino que se practicaban cere-

pueden consultar las obras de $\mathrm{Ph}$. Aries, que ha tratado el terna ampliamente, aunque no de forma directa el siglo vi y vil. Ph. ARIES. Lhomme devant la mort. Paris 1977 (traducción castellana, Madrid 1983)

72 LANTIER. "Le cimetiére wisigothique d'Estagel ...", obra citada, pág. 48. Un artículo diferente, pero del mismo autor y con el mismo titulo, puede consultarse en: Gallia. VII, 1949, pág. 71.

${ }_{73}$ Vives. Concilios visigóticos ..., obra citada, págs. 7-8.

${ }^{74}$ Vives. Concilios Visigóticos ..., obra citada, págs. 7-8. 
monias de mayor envergadura, pero cuyas caracteristicas nos son desconocidas.

Otro texto, aunque más tardio, evidencia una legislación precisa acerca de los ritos que deben o no celebrarse en relación a los difuntos, una vez estos hayan sido inhumados, diciendo claramente que no pueden celebrarse misas encima de las tumbas sino en las basílicas o en los lugares donde estén depositadas las reliquias de los mártires. Se trata del canon LXVIII del Concilio de Braga II, celebrado en el año 572: De eo quod non liceat super monumenta mortuorum missa tenere. Non oportet clericos ignaros et praesumtores super monumenta in campo ministeria portare aut distribuere sacramenta, sed aut in ecclesia aut in basilicas ubi martyrum reliquiae sunt depositae ibi pro defunctis oblationem oferre $^{75}$.

La interdicción de celebrar sepelios de suicidas o criminales y catecúmenos, queda patente, en el canon XVI del Concilio de Braga I, celebrado en el año 561: De his qui se ipsos interficiunt. De his qui sibi quaeumque violentia mortem inferunt ut earum commemoratio in oblatione non fiat, similiter et de his qui pro suis sceleribus puniuntur. Item placuit, ut hii qui sibi ipsis aut ferrum aut per venenum aut per praecipitium aut suspendium vel quolibet modo viclentiam inferunt mortem, nulla illis in oblatione conmemoratio fiat neque cum psalmis ad sepulturam eorum cadavera deducantur; multi enim hoc sibi per ignorantiam usurparunt. Similiter et de his placuit qui pro suis sceleribus puniuntur ${ }^{76}$.

Por el contrario se incita a los fieles que canten salmos, pero no oraciones fúnebres en los entierros de los clérigos y así lo señala el canon XXII del Concilio de Toledo III, del año 589, donde se recoge lo paleocristiano anterior y que se refiere por tanto a la época de unidad confesional: Ut religiosorum corpora sallendo tantum deducantur. Religiosorum omnium corpora qui divina vocatione ab hac vita recedunt cum psalmis tantummodo et sallentium vocibus debere ad sepulchra deferri: nam funebre carmen, quod vulgo defunctis cantare solet, vel peccatoribus se proximos aut familias cedere, omnino prohibemus. Sufficiat autem quod in spe resurrectionis christianorum corporibus famulatum divinorum inpenditur canticorum, prohibet enim nos Apostolus nostros lugere defunctos dicens: "De dormientibus autem nolo vos contristari sicut et ceteri qui spem non habent": et dominus non flevit Lazarum mortuum sed ab huius vitae aerumnas ploravit resuscitandum: si enim potest hoc episco-

\footnotetext{
75 Vives, Concilios visigoticos ..., obra citada., pág. 102.

76 VIVES, Concilios Visigóticos ..., obra citada., pág. 74.
} 
pus, omnium christianorum prohibere agere non moretur; religiosis tamen omnino aliter fieri non debere censemus, sic enim christianorum per omnem mundum humari oportet corpora defunctorum ${ }^{77}$.

En las sepulturas visigodas no existen sacrificia mortuorum de ningún tipo, ni animal, vegetal o de carácter alimenticio, como es habitual en los cementerios merovingios y germánicos del norte de la Gallia y de Europa Central, que entroncan con la más pura creencia y tradición de la mitología escandinava. Aunque existe una legislación conciliar del año 572 que induce a pensar, precisamente porque la prohíbe, que la ofrenda alimenticia era una práctica habitual, aunque no queda constancia de ello arqueológicamente. Es el canon LXIX del Concilio de Braga II, que prohíbe llevar alimentos a las tumbas: De eo quod non liceat christianis prandia ad monumenta portare. Non liceat christianis prandia ad defunctorum sepulcra deferre et sacrificia reddere mortuorum Deo ${ }^{78}$. Sin embargo el reciente estudio de la necrópolis del Camino de los Afligidos (Alcalá de Henares, Madrid), junto con los estudios llevados a cabo en El Cantosal (Segovia) y en El Jardinillo (Madrid) ${ }^{79}$, parece que si aportan evidencias claras sobre depósitos $u$ ofrendas alimenticias dentro de las sepulturas de época visigoda, perpetuándose asi una de las costumbres paganas más antiguas y que debe ser puesta en relación con el banquete funerario.

Los únicos -0 al menos por el momento los más fiables- testimonios arqueológicos que podemos considerar como ofrenda o deposición funeraria son las cerámicas (jarritos, ollas, etcétera) que se han encontrado depositadas en el interior de las sepulturas, por ejemplo en Alconétar (Cáceres), Casa Herrera (Badajoz), Pamplona, San Pedro de Alcántara (Málaga), etc. Todos estos yacimientos son de época visigoda, es decir considerados hispanorromanos y enraizados en las zonas más romanizadas de la Península lbérica o bien de época hispano-visigoda, posteriores a la supuesta unificación étnica y religiosa iniciada por Leovigildo y completada por Recaredo.

También atestigua unas creencias y ritos funerarios, el hecho de que en las necrópolis visigodas "clásicas» se encuentren sepulturas cuyos

17 Vives, Concilios Visigóticos ..., obra citada., págs. 132-133.

'8 VIVES, Concilios Visigóticos ..., obra citada., págs. 132-133.

79 Mendez Madariaga y Rascon Maroues, Los visigodos en Alcalá ..., obra citada, pág. 174. M. C. Priego Fernanoez del Campo, "Excavaciones en la necropolis de El Jardinillo (Getafe, Madrid)". Revista de la Biblioteca, Archivo y Museo del Ayuntamiento de Madrid, 7-8, 1982, pág. 150. M. R. LuCAS Pellicer, "Necrópolis de El Cantosal (Coca, Segovia)", Noticiario Arqueológico Hispánico, II, Madrid 1971, págs. 384-386. 
individuos fueron enterrados con los adornos personales. De un 30 a un 40 por 100 de individuos libres se entierra con sus alhajas personales. La situación varía en el siglo vil y tan sólo un 10 por 100 se lleva consigo a la tumba sus adornos personales. Pero probablemente el hecho de enterrarse con los objetos de adorno personal no corresponde tanto a una problemática ritual, sino a un problema de estratificación social. Por ello, los materiales cerámicos, así como los objetos de adorno personal, y la arquitectura funeraria, deben ser estudiados separadamente.

Estas páginas, han pretendido situar en su contexto algunos de los problemas más importantes que se plantean en el momento de emprender el estudio de la arqueología funeraria de época visigoda en la Península lbérica. Es evidente que algunos problemas sólo se han esbozado y que otros ni siquiera se han planteado, pero creemos que permiten comprender mejor los planteamientos con los que debe enfrentarse el arqueólogo e historiador de esta época, que no es más que el resultado de una continuidad y una innovación, que partiendo desde finales del siglo $v$ se desarrollará hasta los primeros años del siglo vill. 